\title{
Методичний підхід до обґрунтування показників вогневої потужності зенітного ракетного комплексу (системи)
}

\author{
Павло Опенько * А; Павло Дранник А; Вадим Лук'янчук ${ }^{\text {; }}$ \\ Іван Ніколаєв ${ }^{\text {; }}$ І Ігор Дзеверін ${ }^{\text {B }}$ \\ А Національний університет оборони України імені Івана Черняховського, проспект Повітрофлотський, 28, м. Київ, 03049, Україна \\ в Харківський національний університет Повітряних Сил імені Івана Кожедуба, вул. Сумська, 77/79, м. Харків, 61023, Україна
}

Received: July 2, 2020 | Revised: August 13, 2020 | Accepted: August 31, 2020

DOI: $10.33445 /$ sds.2020.10.4.2

\begin{abstract}
Анотація
Результати досліджень, що опубліковано в статті, будуть корисні для фахівців логістичного забезпечення, які займаються питаннями створення (модернізації) зразків озброєння та військової техніки. У статті викладається методичний підхід щодо порядку обґрунтування вимог до показників вогневої потужності перспективного зенітного ракетного комплексу (системи), який передбачає оцінку складових вогневої потужності пошукових можливостей, вогневої продуктивності та вогневого ресурсу з урахуванням інтенсивності нальоту засобів повітряного нападу, дальності і умов застосування зенітного ракетного комплексу (системи) за кожним типом цілей. Наведений перелік показників вогневої потужності, а саме - середній час виявлення і розпізнавання цілі, інтенсивність розвідки цілей, щільність потоку пусків ракет (темп стрільби), час підготовки першого пуску, імовірність ураження цілі, середня витрата ракет на одну ціль. Показано, що показники вогневої потужності перспективного зенітного ракетного комплексу (системи) при заданому рівні захищеності мають визначатись за умови знищення визначеної групи повітряних цілей з ймовірністю, не нижче заданого рівня. Обгрунтування вимог до вогневої потужності перспективного зенітного ракетного комплексу (системи) доцільно здійснювати з використанням комплексу математичних моделей, що забезпечує можливість дослідження сценаріїв конфліктно-інформаційної взаємодії перспективного зенітного ракетного комплексу (системи) і повітряних цілей у вигляді імітаційного машинного експерименту. Показано, що за результатами моделювання повинні визначатись показники пошукових можливостей, вогневої продуктивності і вогневого ресурсу перспективного зенітного ракетного комплексу (системи), а також величина математичного очікування кількості уражених цілей при витраченні зенітних керованих ракет, встановлених на пускових установках.
\end{abstract}

Ключові слова: методичний підхід, зенітний ракетний комплекс (система), вогнева потужність, пошукові можливості, вогнева продуктивність, вогневий ресурс, показники вогневої потужності, математичне моделювання.

\section{Постановка проблеми}

Досвід військових конфліктів останніх десятиліть свідчить, що характер збройної боротьби із засобами повітряного нападу (ЗПН) противника зазнає значних змін. Це обумовлено стрімким розвитком науки i технологій, появою нових типів ЗПН, що впливає на форми і способи дії сил і засобів протиповітряної оборони (ППО). Сучасні погляди на ведення боротьби зі ЗПН противника базуються на тому, що зенітні

\footnotetext{
* Corresponding author: к.т.н., начальник науково-дослідного відділу інституту авіації та протиповітряної оборони, e-mail: pavel.openko@ukr.net, ORCID:
} 0000-0001-7777-5101 
ракетні комплекси (системи) (ЗРК (ЗРС)) у першій четверті XXI столітя будуть складати основу бойової потужності угрупувань ППО важливих адміністративних, промислових і військових об'єктів [1-7].

Для вирішення завдань ППО у майбутній війні ЗРК (ЗРС) повинні мати таку вогневу потужність, яка дала $б$ змогу із заданою ймовірністю забезпечити вирішення завдань боротьби з сучасними та перспективними ЗПн потенційного противника в прогнозованих умовах ведення бойових дій.

\section{Аналіз останніх досліджень та публікацій}

Аналіз відомих публікацій в спеціалізованих науково-технічних виданнях показав, що в даний час публікується велика кількість робіт, які присвячені різним аспектам методології оцінки бойових властивостей зразків ОВТ різного призначення [8-15]. Проте в державних стандартах, розроблених в різний час стосовно різних зразків ОВТ, завдання вимог до вогневої потужності не розглянуте достатньо повно і чітко, що не дозволяє однозначно і обґрунтовано вибирати номенклатуру і рівень показників вогневої потужності конкретних зразків ОВТ. При цьому у відомій науково-технічній літературі [8-15] відсутні роботи, присвячені питанням обґрунтування вимог до вогневої потужності зразків зенітного ракетного озброєння, що не дозволяє обгрунтовано сформулювати тактико-технічне завдання на створення перспективного ЗРК (ЗРС).

Таким чином, проведений аналіз свідчить, що завдання обґрунтування вимог до вогневої потужності зразків зенітного ракетного озброєння $є$ невирішеним, а тема статті актуальною.

\section{Постановка завдання}

Вплив внутрішніх та зовнішніх факторів потребує постійної відповідності існуючих зразків ЗРК (ЗРС) умовам, що склалися. Саме тому виникає необхідність наукового обґрунтування вимог до вогневої потужності, які $€$ одними з важливих і складних завдань, що повинні вирішуватися при розробці тактикотехнічного завдання (ТТЗ) на створення перспективного ЗРК (ЗРС). Для коректного обґрунтування вимог до вогневої потужності перспективного ЗРК (ЗРС) необхідно мати відповідну методику, яка дозволяє вирішувати це завдання спільно з обгрунтуванням вимог до інших ТTX проектованого комплексу (системи).

У зв'язку з цим, наукове завдання полягає в подальшому розвитку науково-методичного апарату визначення номенклатури і порядку оцінювання показників вогневої потужності उРК (ЗPC).

Метою статті є викладення методичного підходу до системного обгрунтування вимог до показників вогневої потужності перспективного ЗРК (ЗРС), які забезпечать вирішення вогневих завдань стосовно боротьби з сучасними і перспективними ЗПН противника в умовах ведення бойових дій, що прогнозуються.

\section{Виклад основного матеріалу}

Функціональне призначення ЗРК (ЗРС) полягає в знищенні ЗПН противника в ході ведення бойових дій. Бойові завдання, які покладаються на ЗРК (ЗРС), умовно можна розділити на завдання ураження і завдання забезпечення ураження 3ПН противника [1114]. Завдання ураження полягає в знищенні максимального числа цілей при витраті певних ресурсів за встановлений час в конкретних умовах ведення бойових дій. Здатність ЗРК (ЗРС) виконувати завдання щодо ураження ЗПН визначається його вогневою потужністю, під якою розуміють здатність комплексу (системи) вирішити обсяг властивих йому бойових завдань відповідно до цільового призначення без урахування або 3 урахуванням радіоелектронно-вогневої протидії противника. Вогнева потужність ЗРК 
(ЗРС) виражається досяжністю, характеристиками бойової частини і точністю наведення зенітних керованих ракет (ЗКР), швидкодією рішення вогневих завдань. Тому необхідно визначити комплексний показник вогневої потужності ЗРК (ЗРС), який має об'єднати всі зазначені характеристики. За досяжність вогню ЗРК (ЗРС) пропонується приймати похилу дальність ефективної стрільби (пусків), на якій значення ймовірності ураження типової цілі однієї ЗКР відповідає заданому значенню.

Методичний підхід до обґрунтування вимог до вогневої потужності перспективного ЗРК (ЗРС) базується на представленні комплексу (системи) як елементу системи зенітного ракетно-артилерійського прикриття (ЗРАП), в якій мета функціонування ЗРК (ЗРС) підпорядкована меті ЗРАП, а сам комплекс (система) розглядається як засіб їі досягнення. В подальшому формулюються основні завдання, які має виконувати ЗРК (ЗРС), та необхідна послідовність їх рішення. Функціонування ЗРК (ЗРС) розбивається на окремі підзадачі, які необхідні і достатні для виконання основних завдань ЗРО; складається схема взаємодії складових частин (бойових засобів) ЗРК (ЗРС), що реалізують сформульовані підзадачі, а потім будується мережева модель їх взаємодії [15]. На підставі цієї моделі розробляється структурно-функціональна схема ЗРК (ЗРС), що визначає основні функціональні підсистеми ЗРК (ЗРС), їх тип, компонування. У якості варіантів структурних схем ЗРК (ЗРС) можуть розглядатися варіанти систем управління наведенням ЗКР і супроводженням цілі, а також варіанти розміщення елементів ЗРК (ЗРС) на одному або декількох бойових засобах.

Вогнева потужність перспективного ЗРК (ЗРС) конкретного типу визначається аналітичним методом або методом математичного моделювання шляхом знаходження математичного очікування числа потенційно знищуваних типових цілей за встановлений час, в заданих умовах бойового застосування, боєкомплектом ЗКР, який знаходиться на пускових установках
(ПУ). Вона залежить від умов бойового застосування ЗРК (ЗРС), які можуть змінюватися в значних межах. Вочевидь, що максимальне значення вогневої потужності матиме місце за умови, коли ЗРК (ЗРС) встигне витратити боєкомплект ЗКР, який знаходиться на ПУ, до моменту його ураження ЗПН противника.

Аналітичний метод визначення вогневої потужності перспективного ЗРК (ЗРС) базується на оцінці математичного очікування число цілей $i$-го типу, яке ЗРК (3PC) може знищити за час існування в умовах вогневої протидії 3 боку противника, в загальному випадку розраховується за формулою[14]:

$$
M_{i}=\overline{m_{i}} P_{n i} P_{\text {обн.i }} P_{\text {обстр. } i} K_{K} K_{\text {Бг }}
$$

де $\overline{m_{i}}-$ середня (очікувана) кількість стрільб, яку ЗРК (ЗРС) може виконати по цілях i-го типу до моменту його ураження або витрачення боєкомплекту ракет, які перебувають на ПУ;

$P_{\text {обн.i }}-$ ймовірність виявлення цілі $i$-го типу;

$P_{\text {обстр.i }}$ - ймовірність обстрілу цілі $і$-го типу;

$P_{n i}-$ ймовірність ураження цілі $i$-го типу за умови її обстрілу $n$ ракетами;

$K_{K}$ - коефіцієнт керованості;

$K_{\text {Бг }}-$ коефіцієнт готовності ЗРК (ЗРС).

Максимальна кількість стрільб ЗРК (ЗРС) по цілях $i$-го типу визначається відношенням запасу ЗКР $Q_{3 к р}$, що знаходиться на ПУ, до

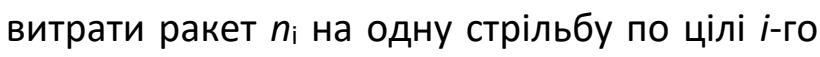

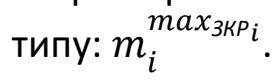

Час ведення бойових дій ЗРК (ЗРС) $t_{\text {Бд }}$ при відбитті нальоту цілей $i$-го типу визначається запасом ЗКР, що знаходиться на ПУ, і темпом стрільби $\eta_{i}: t_{\text {БД } i}=Q_{3 к Р} / \eta_{i}$.

У свою чергу, темп стрільби визначається циклом стрільби $\tau_{i}$, тривалість якого залежить від числа цільових каналів, типу ЗКР, числа ракет в черзі, дальності стрільби, висоти і швидкості цілі: $\eta_{i}=1 / \tau_{i}$.

Тоді очікуваний час ведення бойових дій для багатоканального ЗРК (ЗРС) при відбитті нальоту цілей $і$-го типу визначатиметься за формулою:

$$
t_{5 Д_{i}}=m_{B 3 i} N_{B 3} \tau_{i}
$$


де $m_{B 3 \rightarrow i}-$ математичне очікування числа цілей $i$-го типу, знищених одним вогневим засобом (цільовим каналом) ЗРК (ЗРС) при

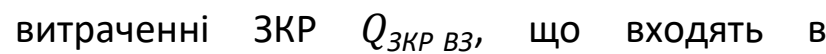
боєкомплект вогневого засобу (цільового каналу), що знаходиться на ПУ;

$N_{\text {Вз }}$ - число вогневих засобів (цільових каналів), що входять до складу ЗРК (ЗРС).

Підготовка початкових даних для оцінювання показника $M_{i}$ включає визначення типів і кількості цілей, з якими повинен вести боротьбу перспективний ЗРК (ЗРС), визначення дальності застосування (параметрів зон виявлення, пуску і ураження) ЗРК (ЗРС) за кожним типом цілей, умов застосування ЗРК (ЗРС) при вирішенні вогневих завдань, способу стрільби, часу доби, радіоелектронної вогневої обстановки та інших чинників.

Узагальненим показником вогневої потужності ЗРК (ЗРС) є ймовірність вирішення комплексу вогневих завдань, що покладаються на перспективний комплекс (систему). Величина цього показника залежить від здатності інформаційних, командно-управляючих, вогневих і технічних засобів, що входять до складу ЗРК (ЗРС) виконувати часткові завдання, що покладаються на них. Таким чином вогнева потужність ЗРК (ЗРС) буде визначатися:

- можливостями засобів розвідки щодо своєчасного виявлення ЗПН в заданих умовах бойового застосування;

- можливостями пункту управління (командного пункту) щодо своєчасного управління вогневими засобами ЗРК (ЗРС), рішення задачі цілерозподілу і видачі цілевказання на вогневі засоби;

- можливостями вогневих засобів ЗРК (ЗРС) щодо знищення ЗПН різних типів;

- можливостями технічних засобів щодо забезпечення функціонування бойових засобів ЗРК (ЗРС) протягом заданого часу.

3 методичної точки зору процедура обґрунтування вимог до вогневої потужності ЗРК (ЗРС) полягає в тому, що спочатку на підставі оперативно-тактичних даних виділяються показники базових властивостей вогневої потужності перспективного ЗРК
(ЗРС), потім визначаються часткові показники, вибираються критерії їх оцінювання, підбирається номенклатура початкових даних та за розрахунковими співвідношеннями, або з використанням математичних моделей, що враховують параметри типових сценаріїв бойових дій, знаходяться значення критеріїв оцінки показників вогневої потужності перспективного ЗРК (ЗРС), які задовольняють необхідному рівню вирішення покладених вогневих завдань.

До базових властивостей вогневої потужності ЗРК (ЗРС) відносяться пошукові (розвідувальні) можливості, вогнева продуктивність і вогневий ресурс.

Частковими показниками вогневої потужності ЗРК (ЗРС) є:

- ймовірність ураження цілі однією ракетою;

- середній час виявлення і розпізнавання цілі розвідувальними засобами ЗРК (ЗРС);

- щільність потоку цілей в нальоті;

- час підготовки ЗКР до пуску і темп стрільби;

- середня витрата ракет на одну ціль.

Розвідувальні можливості складаються 3 можливостей з виявлення цілей (які залежать від дальності і розмірів зони виявлення на різних висотах) та можливостей 3 видачі інформації про повітряні цілі.

Показниками розвідувальних можливостей ЗРК (ЗРС) є:

- інтенсивність розвідки цілей $\gamma_{p}$;

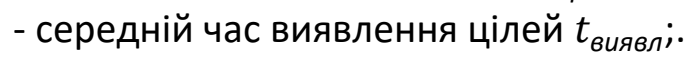

- середній час опізнавання цілей $t_{\text {опізн. }}$

Критеріями оцінки розвідувальних можливостей ЗРК (ЗРС) є:

$\gamma_{p}>\gamma_{p}^{\text {потр }}, t_{\text {виявл }}<t_{\text {виявл }}^{\text {потр }}, t_{\text {опізн }}<t_{\text {опізн }}^{\text {потр }}$

де $\gamma_{p}^{\text {потр }}, t_{\text {виявл }}^{\text {потр }}, t_{\text {опізн }}^{\text {потр }}-$ необхідні значення показників розвідувальних можливостей ЗРК (ЗРC).

Оцінка цих показників здійснюється за співвідношеннями:

$\gamma_{\mathrm{p}}^{\text {потр }}=1 / t_{\text {вияв }}^{\text {потр }}+t_{\text {опізн }}^{\text {потр }} ; t_{\text {виявл }}^{\text {потр }}=\lambda t_{\text {виявл }}^{\mathrm{p}} ; t_{\text {опізн }}^{\text {потр }}=\lambda t_{\text {опізн }}^{\mathrm{p}}$

де $\lambda$ - щільність нальоту $3 П \mathrm{H}$;

$t_{\text {виявл }}^{p} t_{\text {опізн }}^{p}$ - значення часу виявлення та опізнавання цілей, що реалізуються. 
Вогнева продуктивність і вогневий ресурс ЗРК (ЗРС) характеризуються середньою очікуваною кількістю знищених повітряних цілей при відбитті зосередженого удару $3 П \mathrm{H}$ або при витраченні одного боєкомплекту ЗКР, що знаходиться на ПУ ЗРК (ЗРС). Вона залежать від ймовірності ураження цілі однією ракетою, розмірів зони ураження, кількості цілей, що одночасно підлягають обстрілу, і тривалості циклу стрільби.

Частковими показниками вогневої продуктивності ЗРК (ЗРС) є:

- інтенсивність потоку пусків ЗКР $\gamma_{п}$;

- середня витрата ЗКР на ураження однієї цілі $R$;

- ймовірність ураження цілі однією ракетою $P_{1}$;

- час підготовки першого $\left(t_{1}\right)$ і кожного подальшого $\left(t_{2}\right)$ пуску ЗКР.

Критеріями оцінки вогневої продуктивності ЗРК (ЗРС) €:

$\gamma_{\text {п }}<\gamma_{\text {п }}^{\text {потр }}, R_{\mathrm{p}}<R^{\text {потр }} ; P_{1}>P_{1}^{\text {потр }} ; t_{1}>t_{1}^{\text {потр }}, t_{2}>t_{2}^{\text {потр }},(5)$
де $\gamma_{n}^{\text {потр }}, R^{\text {потр }}, P_{1}^{\text {потр }}, t_{1}^{\text {потр }}, t_{2}^{\text {потр }}-$ необхідні значення показників вогневої продуктивності.

Критерієм оцінки вогневого ресурсу ЗРК (ЗРС) $€$ середня кількість цілей, які вражаються одним боєкомплектом ЗКР:
$N_{u}>N_{u}^{\text {потр }}$.

Вирішення комплексу вогневих завдань перспективним ЗРК (ЗРС) В ході бою здійснюється в умовах ведення вогню $3 П \mathrm{H}$ противника у відповідь. Тому ймовірність вирішення вогневих завдань, які покладаються на ЗРК (ЗРС), залежить як від рівня його вогневої потужності, так і від рівня захищеності, яка забезпечує збереження боєздатності ЗРК (ЗPC) i реалізацію його вогневих можливостей. В цілому вимога до вогневої потужності перспективного ЗРК (ЗРС) при заданому рівні його захищеності визначається за умови необхідності перемоги ЗРК (ЗРС) над виділеною групою цілей.

Обгрунтування вимог до вогневої потужності ЗРК (ЗРС) у зв'язку з великою кількістю факторів, які необхідно враховувати при вирішення даного завдання, доцільно здійснювати методами математичного моделювання 3 застосуванням комплексу імітаційних моделей, які описують процеси функціонування ЗРК (ЗРC) у складі угрупування ЗРВ при виконанні завдань 3 прикриття об'єктів в прогнозованих умовах ведення бойових дій (рис. 1).

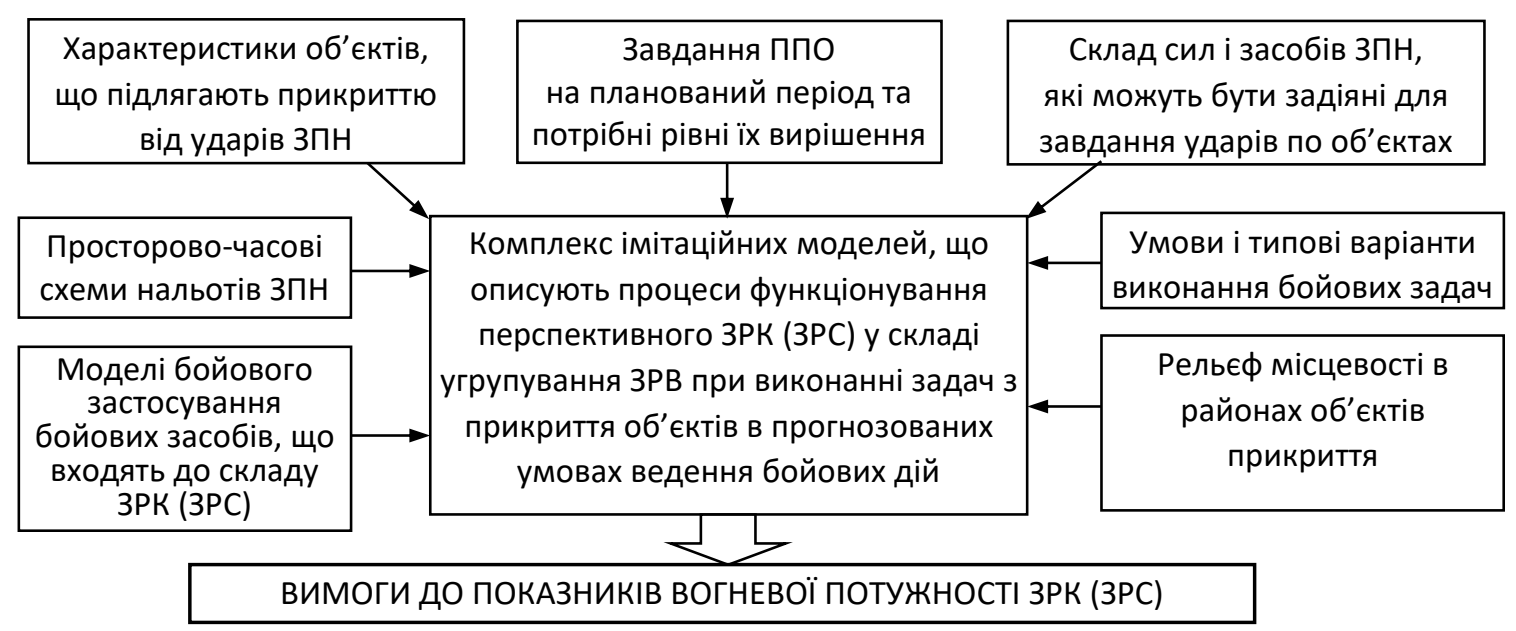

Мал. 1 - Структурна схема обґрунтування вимог до вогневої потужності перспективного ЗРК (ЗРС)

В основу розроблення моделей доцільно покласти сучасні інтерактивні інформаційні технології, які забезпечують можливість дослідження сценаріїв застосування ЗПн і угрупувань ЗРВ у вигляді ігрового імітаційного машинного експерименту [16-19]. Реалізація даного методу передбачає розроблення моделі бойових угрупування ЗРВ, оснащеного перспективними ЗРК (ЗРС), й угрупування повітряного противника, оснащеного сучасними і перспективними ЗПН при відсутності та в умовах інтенсивного застосування 
радіоперешкод і засобів вогневого ураження повітряним противником.

Для розроблення можливих сценаріїв ведення бойових дій перспективним ЗРК (ЗРС) у складі угруповання ЗРВ повинні використовуватися такі дані $[11,14]$ :

- типи, ТTX, варіанти побудови і напрями ударів ЗПН, профілі і траєкторії польоту аеродинамічних і балістичних цілей, наряди ЗПН на засоби ППо і об'єкти, що прикриваються, очікувані рівні перешкод стосовно різних варіантів ведення протиповітряної операції;

- дислокація, розміри, ступінь важливості об'єктів та вимоги до ефективності їх прикриття від ударів 3ПН;

- типи, ТТХ і вартісні характеристики ЗРО, можливі способи його бойового застосування у різних сценаріях ведення протиповітряної операції;

- характер рельєфу місцевості та підстилюючої поверхні у районах об'єктів прикриття та на напрямках імовірних ударів зПН.
За результатами моделювання мають бути отримані потрібні значення показників розвідувальних можливостей, вогневої продуктивності та вогневого ресурсу перспективного ЗРК (ЗРС), на підставі яких розраховуються базові показники його вогневої потужності.

Параметри вогневої потужності перспективного ЗРК (ЗРС) мають відповідати вирішенню наступних завдань:

- забезпечення пошукових можливостей ЗРК (ЗРC) за час, що не перевищує час, необхідний для ураження цілі заданого типу;

- виявлення, розпізнавання і визначення пріоритетів ураження цілей на рубежах, що забезпечують їх своєчасний обстріл заданою кількістю ЗКР;

- забезпечення можливостей своєчасного цілевказання вогневім засобам ЗРК (ЗРС);

- забезпечення можливості ураження цілей заданого типу в межах встановленої зони ураження.

\section{Висновки}

Таким чином, наведений методичний підхід, на відміну від відомих, використовує принципи системного обґрунтування вимог до показників вогневої потужності перспективного ЗРК (ЗРС), які забезпечують сумісне узгоджене обґрунтування вимог до базових і часткових показників вогневої потужності при фіксованих витратах на розроблення і функціонування ЗРК (ЗРС).

Для обґрунтування вимог до показників вогневої потужності перспективного ЗРК (ЗРС) необхідне розроблення математичних моделей його бойового функціонування, побудованих відповідно до структурнофункціонального і сценарного підходів до відображення процесів бойового застосування ЗРК (ЗРС) в рамках виконання розрахункових бойових завдань на типовому розрахунковому оперативно-тактичному фоні. Модель бойового функціонування ЗРК (ЗРС) повинна бути представлена у вигляді структурно-функціонального відображення процесу застосування ЗРК (ЗРС) у складі угрупування ЗРВ, дії якої розглядаються на типовому оперативно-тактичному фоні при виконанні сукупності розрахункових бойових завдань розрахункового сценарію протягом заданого часу (операції, бойових дій).

До основних оцінюваних показників, які характеризують вогневу потужність перспективного ЗРК (ЗРС), можуть бути віднесені бойовий потенціал, коефіцієнт бойового потенціалу, математичне очікування числа знищених цілей, а також часткові показники, що характеризують пошукові можливості, вогневу продуктивність та вогневий ресурс.

Узагальненим показником вогневої потужності ЗРК (ЗРС) є ймовірність вирішення бойового завдання з прикриття об'єкту при відбитті удару ЗПН противника. В умовах протидії противника ймовірність вирішення вогневих завдань, які покладаються на ЗРК (ЗРС), залежить як від рівня його вогневої потужності, так і від рівня захищеності, яка забезпечує збереження боєздатності ЗРК 
(ЗРС) i реалізацію його вогневих можливостей. Реалізація запропонованого підходу вимагає подальшого розвитку відповідних математичних моделей в умовах істотної невизначеності, джерелами якої $\epsilon$ недостатні обсяги фактографічної інформації про фактичний технічний стан парку ЗРК (ЗРС), що дозволяє визначити напрям подальших досліджень.

\section{Список використаних джерел}

1. Лузан А. Г. (2019) Противоракетная и противовоздушная оборона на театрах военных действий: история, реалии и перспективы. Воздушно-космическая $\begin{array}{lll}\text { copepa. } \quad \text { № } 4 . & \text { C. 76-87. URL: }\end{array}$ https://www.vesvks.ru/vks/article/protivorak etnaya-i-protivovozdushnaya-oborona-na-t16470

2. Криницкий Ю. В. (2013) Научноконцептуальный подход к организации ВКО России. Воздушно-космическая оборона. №1. URL: http://www.vko.ru/koncepcii/ nauchno-konceptualnyy-podhod-k-organizaciivko-rossii

3. Захаров В. А., Гладышев В. А. (2007) Основные требования к системе ПВО войск и объектов в современных условиях. Военная мысль. № 1. С. 9-14. URL: http://militaryarticle.ru/voennaya-mysl/2007vm/10038-osnovnye-trebovanija-k-sistemepvo-vojsk-i-obektov

$\begin{array}{lll}\text { 4. Барвиненко } & \text { В. В. (2007) Воздушно- }\end{array}$ космическая оборона: современный аспект. Военная мысль. № 2. С. 8-16. URL: http://www.avnrf.ru/index.php/zhurnalqvoennaya-myslq/323-voennaya-mysl-2-2007

5. Алексеев П., Данилов О. (2006) Состояние и перспективы развития зарубежных ЗРК большой и средней дальности. Зарубежное военное обозрение. № 11. C. 35-43. URL: http://militaryarticle.ru/zarubezhnoe-voennoe -obozrenie/2006-zvo/7419-sostojanie-iperspektivy-razvitija-zarubezhnyh-zrk

6. Болотов Е.Г., Мизрохи Б. Я. (2003) Новое поколение зенитных управляемых ракет средней дальности. Специальный выпуск журнала «Полет» к 50-летию МКБ «Факел», 2003 г. URL: http://pvo.guns.ru/book/fakel/new_gen.htm

7. Акопян И. (2006) Мозг ракеты: особенности построения и тенденции развития головок самонаведения для ракет класса "поверхность-воздух" и "воздух-воздух. Воздушно-космическая оборона. №3 (28). URL: http://militaryarticle.ru/voenno-kosmi cheskaya-oborona/2006/12386-mozg-rakety

8. Баскаков В.В. (2006) Методологические аспекты обоснования перспективного облика системы вооружения. Вестник Академии военных наук. № 2 (15). С. 116122. URL: https://www.elibrary.ru/item.asp ?id $=9250354$

9. Бонин А. С., Фомин М. В. (2009) Основные принципы и методический подход к обоснованию уровневых значений показателей боевых свойств перспективных авиационных комплексов военного назначения. Военная мысль. № 1. С 52-59. URL: http://www.avnrf.ru/index.php/zhurnalqvoennaya-myslq/370-voennaya-mysl-1-2009

10. Бонин А.С. (2005) Боевые свойства и эффективность вооружения и военной техники. Военная мысль. № 1. С. 65-68. URL: http://militaryarticle.ru/voennaya-mysl/2005vm/9478-boevye-svojstva-i-jeffektivnostvooruzhenija-i

11. Ланецкий Б. Н., Лукьянчук В.В., Кириллов И.Г., Николаев И.М. (2004) Порядок обоснования оперативно-тактических требований к системе зенитного ракетного вооружения и еe структурным компонентам. Системи озброєння $i$ військова техніка.№ 1 (37). С. 51-55. URL: http://www.hups.mil.gov.ua/periodic-app/ article/2315

12. Брезгин В.С., Буравлев А.И. (2010) О методологии оценки боевых потенциалов вооружения и военной техники и воинских формирований. Военная мысль. № 8. С. 4148.

13. Буравлев А. И., Цырендоржиев С.Р., Брезгин В. С. (2009) Основы методологического 
подхода к оценке боевых потенциалов образцов ВВТ и воинских формирований. Вооружение и экономика. № 3 (17). С. 4-12.

14. Гриб Д. А., Ланецкий Б. Н., Лук'янчук В. В., Николаев И. М. (2011) Методология оценки боевого потенциала зенитного ракетного вооружения. Артиллерийское и стрелковое вооружение. № 3. С. 9-13. URL: http://lib.sumdu.edu.ua/library/DocDescriptio $\mathrm{n}$ ?d

15. Ланецкий Б.Н., Донцов С.Н. (2004) Аналитическая модель для расчёта эффективности зенитно-ракетного комплекса при отражении заданного налёта средств воздушного нападения. Системи обробки інформачії. № 10 (38). С. 103-111.

16. Богданов О. А., Смирнов А. А., Ковалев Д. В. (2016) Имитационное моделирование противоборства в воздушно-космической сфере. Программные продукты и системы / Software \& Systems № 1 (113), c. 160-164.

17. Ягольников С. В., Смирнов А. А. (2013)
Имитационное моделирование ВКО. Искусство и наука. Воздушно-космическая оборона. № 4. С. 44-51. URL: http://www.vko.ru/koncepcii/imitacionnoemodelirovanie-vko-iskusstvo-i-nauka

18. Ягольников С. В., Каменев А. В. (2006) Виртуальные воздушные войны. Математическое моделирование как инструмент для обоснования перспектив развития ПВО. Воздушно-космическая оборона. № 3. URL: http://www.vko.ru/ koncepcii/virtualnye-vozdushnye-voyny

19. Горчица Г. И., Ищук В. А., Пишков В.Н. (2019) Содержание и направления развития систем имитационного моделирования боевых действий войсковых формирований в полномасштабных технологиях виртуальной реальности. Известия российской академии ракетных и артиллерийских наук. № 1 (106). С. 60-69. URL: https://www.elibrary.ru/item.asp?id= 37098802

\title{
Методический подход к обоснованию показателей огневой мощи зенитного ракетного комплекса (системы)
}

\section{Павел Опенько А ; Павел Дранник ${ }^{\text {; }}$; Вадим Лукъянчук ${ }^{\text {; }}$ Игорь Николаев ${ }^{\text {; }}$ Игорь Дзеверин ${ }^{B}$}

\footnotetext{
"Corresponding author: к.т.н., начальник научно-исследовательского отдела, e-mail: pavel.openko@ukr.net, ORCID: 0000-0001-7777-5101 А Национальный университет обороны Украины имени Ивана Черняховского, проспект Воздухофлотский, 28, г. Киев, 03049, Украина

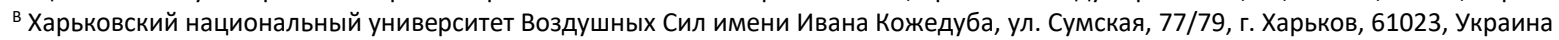

\begin{abstract}
Аннотация
Результаты исследований, опубликованные в статье, будут полезны для специалистов логистического обеспечения, которые занимаются вопросами создания (модернизации) образцов вооружения и военной техники. В статье излагается методический подход к порядку обоснования требований к показателям огневой мощи перспективного зенитного ракетного комплекса (системы), который предусматривает оценку составляющих огневой мощи - поисковых возможностей, огневой производительности и огневого ресурса с учетом интенсивности налета средств воздушного нападения, дальности и условий применения комплекса (системы) по каждому типу целей. Приведенный перечень показателей огневой мощи, а именно - среднее время обнаружения и распознавания цели, интенсивность разведки целей, плотность потока пусков ракет (темп стрельбы), подготовке первого пуска, вероятность поражения цели, средний расход ракет на одну цель. Показано, что показатели огневой мощи перспективного зенитного ракетного комплекса (системы) при заданном уровне защищенности должны определяться при необходимости уничтожения определенной группы воздушных целей с вероятностью не ниже заданного уровня. Обоснование требований к огневой мощи перспективного зенитного ракетного комплекса (системы)
\end{abstract}


целесообразно осуществлять с использованием комплекса математических моделей, что обеспечивает возможность исследования сценариев конфликтно-информационного взаимодействия перспективного зенитного ракетного комплекса (системы) и воздушных целей в виде имитационного машинного эксперимента. Показано, что по результатам моделирования должны определяться показатели поисковых возможностей, огневой производительности и огневого ресурса перспективного зенитного ракетного комплекса (системы), а также величина математического ожидания количества пораженных целей при израсходовании боекомплекта зенитных управляемых ракет, установленных на пусковых установках.

Ключевые слова: методический подход, зенитный ракетный комплекс (система), огневая мощь, поисковые возможности, огневая производительность, огневой ресурс, показатели огневой мощи, математическое моделирование.

\title{
Methodical approach to the substantiation of the indicators of the anti-aircraft missile system (complex) fire power
}

\author{
Pavlo Open'ko A ${ }^{\text {; }}$ Vadym Lukyanchuk ${ }^{\text {B }}$; Ivan Nikolaev ${ }^{\text {B }}$; \\ Igor Dzeverin ${ }^{B}$; Pavlo Drannyk ${ }^{A}$
}

*Corresponding author: Ph.D.in Technical Science, Head of the Scientific-research, e-mail: pavel.openko@ukr.net, ORCID: 0000-0001-7777-5101 A The National Defence University of Ukraine named after Ivan Cherniakhovskyi, 28, Povitroflotskyi Ave., Kyiv, 03049, Ukraine,

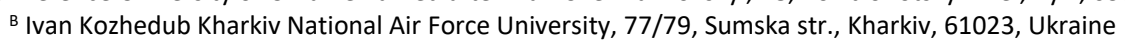

\begin{abstract}
The results of the research published in the article will be useful for logistic support specialists who are involved in the creation (modernization) of the samples of weapons and military equipment. A methodical approach to substantiating the firepower requirements of a promising anti-aircraft missile system (system) is presented, which provides for the assessment of the components of firepower - search capabilities, firepower and fire resource, taking into account the intensity of the air attack, range and conditions of use of the complex (systems) for each type of goal. A list of indicators of firepower is given, namely, the average time of detection and recognition, the intensity of reconnaissance of targets, the density of the flow of missile launches (rate of fire), the preparation time of the first launch, the probability of hitting a target, and the average consumption of missiles per target. It is shown that the firepower indicators of a promising anti-aircraft missile system (system) at a given level of protection should be determined provided that it is necessary to defeat a selected group of air targets with a probability of not lower than a given level. The requirements for the firepower of a promising anti-aircraft missile system (system) can be substantiated using a complex of mathematical models that provide the opportunity to study scenarios of conflict-information interaction of a promising anti-aircraft missile system (system) and air targets in the form of a simulation machine experiment. It is shown that, based on the simulation results, the indicators of search capabilities, fire performance and fire resource of a promising anti-aircraft missile complex (system), as well as the mathematical expectation of the number of people hit by the whole when the ammunition load of anti-aircraft guided missiles installed on launchers are used, should be determined.
\end{abstract}

Keywords: methodical approach, anti-aircraft missile system (system), firepower, search capabilities, firepower, fire resource, firepower indicators, mathematical modeling.

\section{References}

1. Luzan, A. G. (2016) "Protivoraketnaya i protivovozdushnaya oborona na teatrakh voyennykh deystviy: istoriya, realii i perspektivy" [Missile and air defense in theaters of operations: history, realities and prospects], Aerospace sphere, No. 4, pp. 76-87. 
https://www.vesvks.ru/vks/article/protivorake tnaya-i-protivovozdushnaya-oborona-na-t16470 [in Russian]

2. Krinitskiy, Yu. V. (2013) "Nauchnokontseptual'nyy podkhod k organizatsii VKO Rossii" [Scientific-conceptual approach to the organization of the aerospace defense of Russia], Aerospace defense, No. 1. http://www.vko.ru/koncepcii/nauchno-

konceptualnyy-podhod-k-organizacii-vko-rossii [in Russian]

3. Zakharov, V. A. (2007) "Osnovnyye trebovaniya k sisteme PVO voysk i ob"yektov v sovremennykh usloviyakh" [Basic requirements for the air defense system of troops and objects in modern conditions], Military Thought, No. 1, pp. 9-14. http://militaryarticle.ru/voennaya-mysl/2007vm/10038-osnovnye-trebovanija-k-sistemepvo-vojsk-i-obektov [in Russian]

4. Barvinenko, V. V. (2007) "Vozdushnokosmicheskaya oborona: sovremennyy aspekt" [Aerospace defense: a modern aspect], Military Thought, No. 2, pp. 8-16. http://www.avnrf.ru/index.php/zhurnalqvoennaya-myslq/323-voennaya-mysl-2-2007 [in Russian]

5. Alekseyev P., Danilov O. (2006) "Sostoyaniye i perspektivy razvitiya zarubezhnykh ZRK bol'shoy i sredney dal'nosti" [State and prospects of development of foreign air defense systems of long and medium range]. Foreign Military Review, No. 11, pp. 35-43. http://militaryarticle.ru/zarubezhnoe-voenn oe-obozrenie/2006-zvo/7419-sostojanie-i-per spektivy-razvitija-zarubezhnyh-zrk [in Russian]

6. Bolotov E.G., Mizrokhi B. Ya. (2003) “Novoye pokoleniye zenitnykh upravlyayemykh raket sredney dal'nosti" [A new generation of medium-range anti-aircraft guided missiles]. Special issue of the magazine "Flight" to the 50th anniversary of the Fakel ICB. http://pvo.guns.ru/book/fakel/new_gen.htm [in Russian]

7. Akopyan I. (2006) "Mozg rakety: osobennosti postroyeniya i tendentsii razvitiya golovok samonavedeniya dlya raket klassa "poverkhnost'-vozdukh" i "vozdukh-vozdukh" [Missile brain: features of construction and development trends of homing heads for surface-to-air and air-to-air missiles], Aerospace Defense, No. 3 (28). http://militaryarticle.ru/voenno-kosmicheska ya-oborona/2006/12386-mozg-rakety [in Russian]

8. Baskakov, V. V. (2006) "Metodologicheskiye aspekty obosnovaniya perspektivnogo oblika sistemy vooruzheniya" [Methodological aspects of the justification of the promising appearance of the weapons system], Bulletin of the Academy of Military Sciences, No. 2 (15), pp. 116-122. https://www.elibrary.ru/ item.asp?id=9250354 [in Russian]

9. Bonin, A. S., Fomin, M. V. (2009) "Osnovnyye printsipy i metodicheskiy podkhod $k$ obosnovaniyu urovnevykh znacheniy pokazateley boyevykh svoystv perspektivnykh aviatsionnykh kompleksov voyennogo naznacheniya" [Basic principles and methodological approach to the substantiation of level values of the combat properties of promising military aviation systems], Military Thought, No. 1, pp. 52-59. [in Russian]

10. Bonin, A. S. (2005) "Boyevyye svoystva i effektivnost' vooruzheniya i voyennoy tekhniki" [Combat properties and the effectiveness of weapons and military equipment], Military Though, No. 1, pp. S. 6568. [in Russian]

11. Lanetskiy, B. N., Luk'yanchuk, V. V., Kirillov, I. G., Nikolaev, I. M. (2014) "Poryadok obosnovaniya operativno-takticheskikh trebovaniy $\mathrm{k}$ sisteme zenitnogo raketnogo vooruzheniya i yeye strukturnym komponentam" [The order of substantiation of operational and tactical requirements for the anti-aircraft missile weapons system and its structural components], Systems of Arms and Military Equipment, No. 1 (37), pp. 51-55. [in Russian]

12. Brezgin V. S., Buravlev A. I. (2010) O metodologii otsenki boyevykh potentsialov vooruzheniya i voyennoy tekhniki i voinskikh formirovaniy [On the methodology for assessing the combat potentials of weapons and military equipment and military units], No. 8. pp. $41-48$ 
13. Buravlev A. I., Tsyrendorzhiev S. R, Brezgin V.S. (2009) Osnovy metodologicheskogo podkhoda $\mathrm{k}$ otsenke boyevykh potentsialov obraztsov VVT i voinskikh formirovaniy [Fundamentals of the methodological approach to assessing the combat potentials of military and military equipment and military units], Armament and Economics. No. 3 (17). pp. 4-12. [in Russian]

14. Grib, D. A., Lanetskiy, B. N., Luk'yanchuk, V. V., Nikolaev, I. M. (2011) "Metodologiya otsenki boyevogo potentsiala zenitnogo raketnogo vooruzheniya" [Methodology for assessing the combat potential of anti-aircraft missile weapons], Artillery and small arms, No. 3, pp. 9-13. http://lib.sumdu.edu.ua/library/ DocDescription?d [in Russian]

15. Lanetsky B.N., Dontsov S.N. (2004). "Analiticheskaya model' dlya raschota effektivnosti zenitno-raketnogo kompleksa pri otrazhenii zadannogo nalota sredstv vozdushnogo napadeniya" [An analytical model for calculating the effectiveness of an anti-aircraft missile system when reflecting a given raid of air attack means], Systems for processing information, No. 10 (38), pp. 103111.

16. Bogdanov, O. A., Smirnov, A. A, Kovalev, D. V. (2016). "Imitatsionnoye modelirovaniye protivoborstva $v$ vozdushno-kosmicheskoy sfere" [Simulation modeling of confrontation in the aerospace sphere], Software \& Systems, No. 1 (113), pp. 160-164.
17. Yagol'nikov, S. V., Smirnov A. A. (2013). "Imitatsionnoye modelirovaniye VKO. Iskusstvo i nauka" [Simulation modeling of aerospace defense. Art and science], Aerospace defense, No. 4. pp. 44-51. http://www.vko.ru/koncepcii/imitacionnoemodelirovanie-vko-iskusstvo-i-nauka [in Russian]

18. Yagol'nikov, S. V., Kamenev, A. V. (2006). "Virtual'nyye vozdushnyye voyny. Matematicheskoye modelirovaniye kak instrument dlya obosnovaniya perspektiv razvitiya PVO" [Virtual Air Wars. Mathematical modeling as a tool for substantiating the development prospects of air defense], Aerospace defense, No. 3. http://www.vko.ru /koncepcii/virtualnye-vozdushnye-voyny [in Russian]

19. Gorchitsa G. I., Ishchuk, V. A., Pishkov, V. N. (2019). "Soderzhaniye i napravleniya razvitiya sistem imitatsionnogo modelirovaniya boyevykh deystviy voyskovykh formirovaniy $v$ polnomasshtabnykh tekhnologiyakh virtual'noy real'nosti" [The content and directions of development of simulation systems for combat operations of military units in full-scale virtual reality technologies], Letters of the Russian academy of rocket and artillery sciences, No. 1 (106), pp. 60-69. https://www.elibrary.ru/item.asp?id=3709880 [in Russian] 